\title{
Health and economic impact of human papillomavirus 16 and 18 vaccination of preadolescent girls and cervical cancer screening of adult women in Peru
}

\author{
Sue J. Goldie, ${ }^{1}$ Carol Levin, ${ }^{2}$ N. Rocio Mosqueira-Lovón, ${ }^{3}$ \\ Jesse Ortendahl, ${ }^{1}$ Jane Kim, ${ }^{1}$ Meredith O'Shea, ${ }^{1}$ \\ Mireia Diaz Sanchez, ${ }^{4}$ and Maria Ana Mendoza Araujo ${ }^{5}$
}

Suggested citation

Goldie SJ, Levin C, Mosqueira-Lovón NR, Ortendahl J, Kim J, O'Shea M, et al. Health and economic impact of human papillomavirus 16 and 18 vaccination of preadolescent girls and cervical cancer screening of adult women in Peru. Rev Panam Salud Publica. 2012;32(6):426-34.

ABSTRACT Objective. To estimate the benefits, cost-effectiveness (i.e., value for money), and required financial costs (e.g., affordability) of adding human papillomavirus (HPV) vaccination to Peru's cervical cancer screening program.

Methods. Evidence (e.g., coverage, delivery costs) from an HPV vaccination demonstration project conducted in Peru was combined with epidemiological data in an empirically calibrated mathematical model to assess screening (HPV DNA testing three to five times per lifetime) and HPV vaccination under different cost, coverage, and efficacy assumptions. Model outcomes included lifetime risk of cancer reduction, cancer cases averted, lives saved, average life expectancy gains, short-term financial costs, and discounted long-term economic costs.

Results. Status quo low levels of screening (e.g., cytologic screening at $10.0 \%$ coverage) reduced lifetime risk of cervical cancer by $11.9 \%$, compared to not screening. Adding vaccination of preadolescent girls at a coverage achieved in the demonstration program (82.0\%) produced an additional $46.1 \%$ reduction, and would cost less than US\$ 500 per year of life saved (YLS) at $\sim$ US\$ 7/dose or US\$ 1300 at US\$20/dose. One year of vaccination was estimated to cost $\sim$ US\$ 5 million at $\sim$ US\$ 5/dose or $\sim$ US\$ 16 million at $\sim$ US\$ 20/dose, including programmatic costs. Enhanced screening in adult women combined with preadolescent vaccination had incremental cost-effectiveness ratios lower than Peru's 2005 per capita gross domestic product (GDP; US\$ 2 852, in 2009 US\$), and would be considered cost-effective.

Conclusions. Preadolescent HPV vaccination, followed by enhanced HPV DNA screening in adult women, could prevent two out of three cervical cancer deaths. Several strategies would be considered "good value" for resources invested, provided vaccine prices are low. While financial costs imply substantial immediate investments, the high-value payoff should motivate creative mechanisms for financing and scale-up of delivery programs.

Key words Papillomavirus infections; uterine cervical neoplasms; papillomavirus vaccines; vaccination; cost-effectiveness evaluation; Peru.

1 Center for Health Decision Science, Harvard School of Public Health, Boston, Massachusetts, United States of America. Send correspondence to Sue J. Goldie, sue_goldie@harvard.edu

2 PATH, Seattle, Washington, United States of America.
Instituto de Investigación Nutricional, Lima, Peru.

4 Institut Català d'Oncologia, Barcelona, Spain.

5 Estrategia Sanitaria Nacional de Inmunizaciones,

Ministerio de Salud, Lima, Peru.
Cervical cancer is a disease of poverty and inequity. Although infection with high-risk types of human papillomavirus (HPV) - the causal agent of cervical cancer-is common worldwide, 
the risk of dying from cervical cancer is disproportionately borne by relatively young women in developing countries $(1,2)$. Peru's age-standardized rate of cervical cancer incidence is 34.5 per 100000 women per year, compared to 17.7 in developing regions (1). In 2010, the United Nations estimated that more than 10 million women were older than age 15 and at risk for cervical cancer in Peru (3). Based on current rates of cervical cancer, and considering demographic changes without making assumptions about temporal changes in cancer risk, the number of expected new cases is expected to rise significantly $(1,2)$.

Currently available options to reduce the global burden of cervical cancer include primary prevention with preadolescent HPV 16 and 18 vaccination of girls and secondary prevention in women over age 30 with screening strategies that employ alternatives to cytology. Two HPV vaccines are highly effective in preventing infection with the most common oncogenic types of HPV (e.g., 16 and 18), if administered to preadolescent girls $(4,5)$. Novel secondary prevention techniques for women not eligible for vaccination include the use of rapid HPV DNA testing or visual inspection with acetic acid; both will theoretically allow for same-day screening and treatment of cervical lesions (6).

Previous model-based analyses specific to Peru have provided preliminary estimates of the expected cancer reduction with HPV 16 and 18 vaccination and new screening technologies (7-9) and identified strategies that would be considered cost-effective. Yet no cost-effectiveness studies to date have incorporated empirical data on the country-specific costs of vaccine delivery, achievable coverage, and proportion completing three doses.

In 2008, Peru became one of the first Latin American countries to pilot the introduction of the HPV vaccine through a school-based strategy to reach girls in grade 5 aged 9 years or older (10-13). The pilot (10) involved three regions (Ayacucho, Piura, and Ucayali) and was implemented by the National Expanded Program for Immunization (Estrategia Sanitaria Nacional de Inmunizaciones, ESNI) of the Ministry of Health (Ministerio de Salud, MINSA), with technical support from PATH (Seattle, Washington, USA), and evaluated by MINSA/ ESNI, PATH, and the Instituto de Investigación Nutricional (IIN; Lima, Peru).
IIN evaluated vaccine coverage, acceptability, and feasibility of the strategies implemented in the demonstration project, while MINSA/ESNI and PATH collaborated to estimate the associated costs $(10,12,14)$.

The empirical data derived from this demonstration project were used to inform a previously validated model of cervical cancer prevention strategies in Peru. Motivated to contribute to the information needed by decision-makers that inform immunization policy recommendations and vaccine adoption decisions in Peru, the authors used this model to assess benefits, cost-effectiveness, and financial cost requirements of new opportunities to prevent cervical cancer through an optimal combination of vaccination, screening, and treatment.

\section{MATERIALS AND METHODS}

\section{Overview}

Evidence (e.g., coverage, delivery costs) from an HPV vaccination demonstration project conducted in Peru was combined with epidemiological data in an empirically calibrated computerbased simulation model to assess screening (HPV DNA testing three to five times per lifetime) and HPV vaccination under different cost, coverage, and efficacy assumptions. The individual-based Monte Carlo simulation model represents the natural history of disease as a sequence of monthly transitions between mutually exclusive health states that distinguish HPV infection with type 16, type 18, other high-risk types, and other low-risk types; cervical intraepithelial neoplasia (CIN) grade 1 (CIN1) and CIN grades 2 and 3 (CIN2 and CIN3); and local, regional, and distant cervical cancer. Girls and women transition between health states according to transition probabilities (i.e., model input parameters) that depend on HPV type, age, history of previous HPV infection, type-specific natural immunity, previously treated CIN, and screening pattern. The methods used to calibrate the model to country- and/or region-specific epidemiological data are described in more detail elsewhere $(8,15-22)$. The authors of the current study compared HPV 16,18 vaccination policies targeting preadolescent girls, screening strategies targeting women over age 30 utilizing HPV DNA testing three or five times per lifetime, and combined vaccination and screening. The selected strategies (screening and treatment of 35-year-old women; vaccination of 11-year-old girls) were assumed to be applied concurrently.

Model outcomes included reduction in the lifetime risk of cancer, cancer cases averted, lives saved, average gains in life expectancy, short-term financial costs, and discounted long-term (lifetime) economic costs. Estimates were made of the cost-effectiveness (i.e., value for money) of adding HPV vaccination to Peru's screening program, as well as the required financial costs (e.g., affordability).

\section{Strategies and assumptions}

In the base-case analysis, the authors assessed the impact of combined preadolescent vaccination and status quo screening (current standard practice). Vaccination occurs on average at age 11, prior to sexual debut, and may be combined with screening. In the original scenario, it was assumed that $82.0 \%$ of the target population receives three doses on average, which provide full, lifelong, type-specific protection against HPV 16 and 18. Status quo screening in Peru was defined as annual cervical cytology (at $10.0 \%$ coverage of women 35-55 years old) requiring three visits for screening, diagnostics, and treatment.

In sensitivity analyses, vaccine efficacy and coverage were varied, and alternative assumptions regarding lifelong immunity were assessed. The base-case vaccine cost was $\sim$ US $\$ 7$ per dose, varied in sensitivity analyses from $\sim$ US $\$$ to US\$ 20 per dose. In an extended analysis, alternative screening strategies were considered, either alone or combined with preadolescent vaccination. These enhanced screening strategies target women 35-55 years old three or five times per lifetime (with screening at fiveyear intervals) using HPV DNA testing at various coverage levels. HPV DNA testing is performed in two visits (with initial screening in the first visit, and diagnostics and same-day treatment in the second visit), and those not eligible for same-day treatment are referred to a secondary facility for further diagnostic testing and, if necessary, treatment.

\section{Data}

Epidemiological data and screening test performance data are described as 
supplementary material. ${ }^{6}$ Vaccine coverage was based on data reported locally through a Spanish-language technical report, which described achievement of over $80.0 \%$ coverage for all three doses among girls eligible for the HPV vaccine program $(10,23)$. Based on the countryspecific data, which showed vaccination coverage rates ranging from $79.3 \%$ to $85.6 \%, 82.0 \%$ coverage was assumed for the base case. A plausible range for sensitivity analysis was based on data provided by the HPV Vaccines: Evidence for Impact project conducted by PATH in collaboration with ministries of health and other partners to assess vaccine introduction in four countries (India, Peru, Uganda, and Vietnam) (24). Based on coverage rates reported in the four countries, sensitivity analysis was conducted for coverage rates ranging from $61.0 \%$ to $98.0 \%$ (24).

Data from the costing study embedded in the demonstration project $(10,12$, 14) were used to inform cost parameters in the model. Methods and assumptions for the process used to identify, measure, and value costs are documented in the supplementary material. Briefly, the incremental costs of introducing the new vaccine into Peru included start-up costs (e.g., for micro-planning, sensitization, mobilization, and supervision) and recurrent costs of HPV implementation (e.g., for immunization supplies; vaccine supply chain logistic costs; mobilization for vaccination, such as transport to vaccination sites; and salaries and per diems for personnel). Depreciation of existing capital for cold chain equipment and vehicles, as well as personnel salaries, are included in these estimates to capture the opportunity cost of resources used for vaccine delivery.

Program costs included those associated with vaccine introduction and delivery, and were assessed within each of the following zones: urban, rural, and remote rural. Since cost data were collected from a sample of facilities across the three zones, a weighted average cost per dose was used to capture the share of the target population living in each zone (see Appendix). The average program cost per girl vaccinated with all three doses was US\$ 7.61 (in 2005 US\$).

Because the public sector price of the vaccine has been declining rapidly, a vaccine cost per dose ranging from

\footnotetext{
6 http://bit.ly/VPN4ZX
}

US\$ 5 to US\$ 20 per dose was used to capture future possible prices (25). For each dose, the project-based wastage rate of $2.0 \%$ for single-dose vials and freight costs based on World Health Organization (WHO) estimates of $6.0 \%$ of the vaccine price $(26,27)$ were applied.

The average unit costs for cervical cancer screening, diagnosis, treatment of precancerous lesions, and treatment of different states of cancer were estimated from primary and secondary data. Primary data were collected in 2007 from the National Institute of Cancer (Instituto Nacional de Enfermedades Neoplásicas, INEN); regional hospitals in Piura, Ayacucho, and Ucayali; and a convenience sample of facilities in each region where screening occurs only with cytology. This selection of facilities was illustrative of the range of public health care institutions and the expected quality of care and costs found in the public health system in Peru. Resource use for each stage of cancer was based on clinical protocols from national and regional hospitals, and interviews with hospital personnel. Project staff interviewed health care providers and hospital administrators to obtain information on staff time, salaries, clinical consumable supplies, laboratory supplies, clinical and laboratory equipment, and indirect costs involved in all cervical cancer screening, diagnosis, and treatment services. Supplementary budgetary data and expenditure records were used to provide information on salaries of nonclinical staff and indirect costs that comprise facility overhead costs.

Costs associated with screening, including direct medical costs (e.g., for staff, disposable supplies, equipment, and specimen transport) and program delivery costs, were estimated from the demonstration project. Estimates of women's time and transport costs were based on previously published data (7, 28-32).

HPV vaccination and cervical cancer screening, diagnosis, treatment, and indirect costs were converted to local currency units, adjusted for inflation using country-specific inflation rates, and converted to 2005 US\$ using exchange rates (28).

\section{Cost-effectiveness analysis}

The performance of alternative strategies was measured using incremental cost-effectiveness ratios, defined as the additional cost of a specific strategy, divided by its additional benefit, compared with the next most costly strategy (cost [US\$]/year of life saved [YLS]). Recommendations from published guidelines for economic evaluations intended to inform resource allocation were followed in that a societal perspective was adopted and all costs and benefits were included regardless of to whom they accrued, patient time costs were incorporated, and future costs and life years were discounted by $3.0 \%$ annually (31, 33-35). Although there is no consensus on a specific cost-effectiveness threshold, below which an intervention would be considered cost-effective, one suggested heuristic has been the country's per capita gross domestic product (GDP) (36); realistically the threshold ratio may need to be much lower for the intervention to be affordable. Strategies with costeffectiveness ratios lower than Peru's 2005 per capita GDP (US\$ 2 852, in 2009 US\$) (28) were considered cost-effective.

\section{RESULTS}

\section{Projected clinical outcomes}

Clinical outcomes are shown in Table 1. Status quo screening (low coverage, $10.0 \%)$ reduced the lifetime risk of cancer by $11.9 \%$, and averted roughly 1000 cases of cancer per birth cohort. The base-case strategy of adding preadolescent vaccination at $82.0 \%$ coverage to status quo screening reduced cancer by more than $50.0 \%$ and averted nearly 5500 cervical cancer cases. Over the course of one birth cohort, this strategy saved more than 80000 life years-more than three times the number saved with status quo screening alone.

Results of the extended analysis indicated $82.0 \%$ vaccine coverage, adopting HPV DNA testing at 75\% coverage, increased the cancer risk reduction by an additional $15.0 \%$ compared to vaccination combined with cytologic screening at $10 \%$ coverage (Table 2 ).

The impact of alternative coverage rates is shown in Figure 1. When considering only the base case (combined status quo screening at $10.0 \%$ coverage with preadolescent vaccination), varying vaccination coverage from $61.0 \%$ to $98.0 \%$ resulted in a corresponding reduction in cervical cancer $(34.4 \%$ to $55.1 \%$ ), compared with status quo 
TABLE 1. Base case analysis: health outcomes associated with HPV 16 and 18 vaccination ( $82.0 \%$ coverage) of preadolescent girls, based on empirical data from an immunization pilot project collected in three regions, ${ }^{b}$ Peru, 2008-2009c

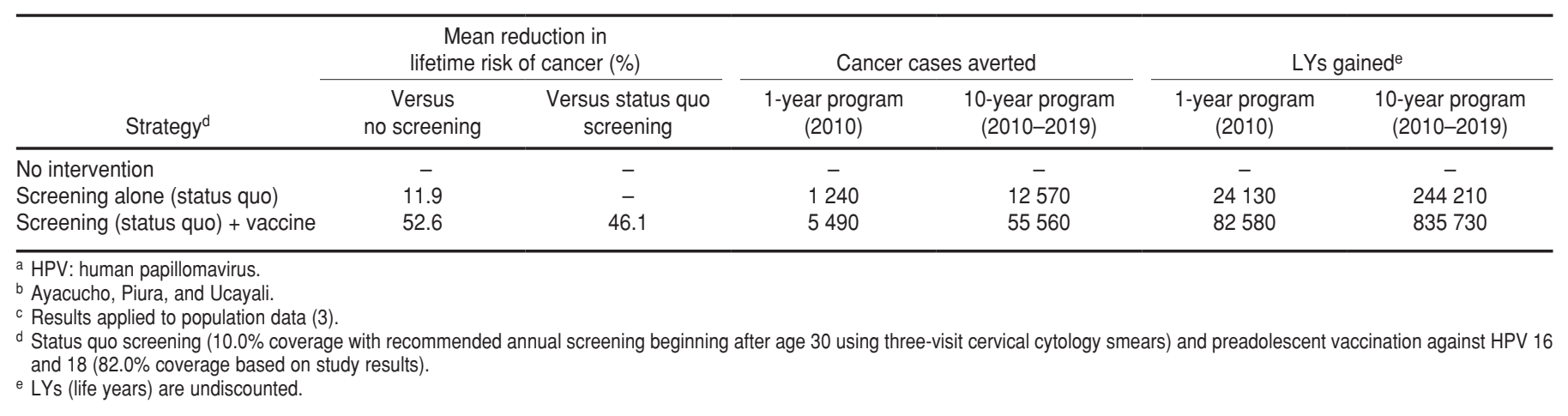

TABLE 2. Extended analysis: health outcomes associated with HPVa 16 and 18 vaccination ( $82.0 \%$ coverage) of preadolescent girls and various screening strategies, based on empirical data from an immunization pilot project and epidemiological data from cervical cancer screening collected in three regions, ${ }^{b}$ Peru, 2006-2009c

\begin{tabular}{|c|c|c|c|c|c|}
\hline \multirow[b]{2}{*}{$\begin{array}{c}\text { Strategy }^{d} \\
\text { (vaccination coverage 82.0\%) }\end{array}$} & \multirow[b]{2}{*}{ Screening frequency } & \multirow[b]{2}{*}{$\begin{array}{c}\text { Screening } \\
\text { coverage (\%) }\end{array}$} & \multicolumn{2}{|c|}{$\begin{array}{c}\text { Mean reduction in } \\
\text { lifetime risk of cancer (\%) }\end{array}$} & \multirow{2}{*}{$\begin{array}{c}\text { Number of deaths } \\
\text { averted over lifetime of } \\
10 \text { birth cohorts (2009-2019), } \\
\text { per strategy, compared to } \\
\text { status quo screening }\end{array}$} \\
\hline & & & $\begin{array}{c}\text { Versus } \\
\text { no screening }\end{array}$ & $\begin{array}{c}\text { Versus } \\
\text { status quo screening }\end{array}$ & \\
\hline No intervention & - & - & - & - & - \\
\hline Screening alone (status quo) & Annual (cytology) & 10.0 & 11.9 & - & - \\
\hline \multirow{2}{*}{$\begin{array}{l}\text { Screening (status quo) + vaccine } \\
\text { Screening alone }\end{array}$} & Annual (cytology) & 10.0 & 52.6 & 46.1 & 27310 \\
\hline & $\begin{array}{l}\text { Three times per lifetime } \\
\text { (HPV DNA testing) }\end{array}$ & 25.0 & 10.4 & 0.0 & 0 \\
\hline Screening + vaccine & $\begin{array}{l}\text { Three times per lifetime } \\
\text { (HPV DNA testing) }\end{array}$ & 25.0 & 51.7 & 45.1 & 26720 \\
\hline Screening alone & $\begin{array}{l}\text { Three times per lifetime } \\
\text { (HPV DNA testing) }\end{array}$ & 75.0 & 26.3 & 16.4 & 9720 \\
\hline Screening + vaccine & $\begin{array}{l}\text { Three times per lifetime } \\
\text { (HPV DNA testing) }\end{array}$ & 75.0 & 60.3 & 54.9 & 32530 \\
\hline Screening alone & $\begin{array}{l}\text { Five times per lifetime } \\
\text { (HPV DNA testing) }\end{array}$ & 25.0 & 16.2 & 4.9 & 2900 \\
\hline Screening + vaccine & $\begin{array}{l}\text { Five times per lifetime } \\
\text { (HPV DNA testing) }\end{array}$ & 25.0 & 55.0 & 48.9 & 28970 \\
\hline Screening alone & $\begin{array}{l}\text { Five times per lifetime } \\
\text { (HPV DNA testing) }\end{array}$ & 75.0 & 39.0 & 30.9 & 18310 \\
\hline Screening + vaccine & $\begin{array}{l}\text { Five times per lifetime } \\
\text { (HPV DNA testing) }\end{array}$ & 75.0 & 67.5 & 63.1 & 37380 \\
\hline
\end{tabular}

screening alone. Even at the lowest estimate of $61.0 \%$ coverage, mean cancer reduction with vaccination and status quo screening $(34.4 \%)$ was still more than double the reduction achieved with status quo screening alone (11.9\%; see Table 1). In the extended analysis, vaccination combined with HPV DNA screening reduced a greater amount of cancer than when combined with the current cytology screening program, with the exception of HPV DNA test- ing at $25.0 \%$ coverage three times in a lifetime, which provides a comparable benefit. Additional results are provided in the Appendix.

\section{Cost-effectiveness analysis}

In Peru, using the data collected for programmatic HPV vaccine costs, and assuming a cost per vaccinated girl of US\$ 30.33 (per dose cost of $\sim$ US\$ 7), the base-case analysis of adding preadoles- cent vaccination to the status quo screening program would be less than US\$ 500 per YLS, compared to status quo screening (Table 3). At a cost per vaccinated girl of US\$ 23.84 ( US\$ 5 per dose), the cost per YLS was less than US\$ 300; at a cost per vaccinated girl of US\$ 72.48 ( US\$ 20 per dose), the cost per YLS was approximately US\$ 1300.

The cost-effectiveness ratios of adding enhanced screening of adult women to vaccination of preadolescent girls 
FIGURE 1. Impact of preadolescent HPV 16 and 18 vaccination coverage on reduction in lifetime risk of cervical cancer for various strategies employing screening and vaccination, based on empirical and epidemiological data from Ayacucho, Piura, and Ucayali, Peru, 2006-2009a-d

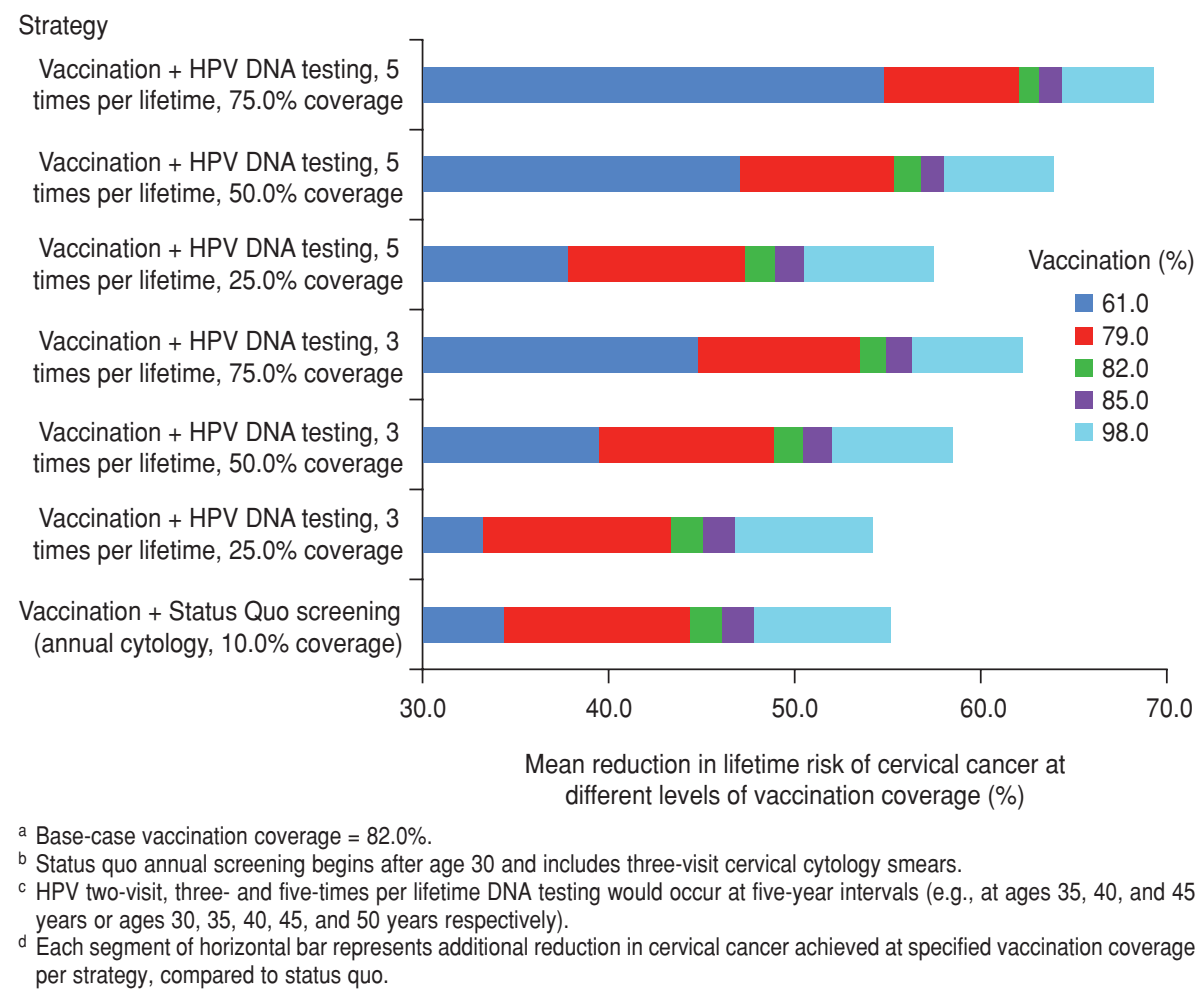

were higher, but these strategies provide greater benefits, and because the costeffectiveness ratios were lower than the 2005 per capita GDP in Peru (US\$2 852), they were still considered cost-effective.

\section{Sensitivity analyses}

The base-case vaccination strategy assumed $100.0 \%$ efficacy over the lifetime of a vaccinated girl. If efficacy of the vaccine is as low as $70.0 \%$, cancer reduction is projected to decline from $46.1 \%$ to $28.0 \%$ when combined with status quo screening in Peru. Enhanced screening is expected to attenuate the reduction in benefit associated with assumptions of lower vaccine efficacy. Similarly, the cost-effectiveness of vaccination strategies was sensitive to waning, with incremental cost-effectiveness ratios increasing (i.e., becoming less cost-effective) if the vaccine wanes within 10 years (Appendix Table A5).

Sensitivity analysis showed results were also sensitive to assumptions about cancer treatment costs and discounting rates of future benefits. Using a second source of cost data, described in the Appendix, which showed higher cancer treatment costs, cost-effectiveness ratios became more favorable; conversely, if treatment costs were reduced by $50.0 \%$, cost-effectiveness ratios were only slightly higher than those found in the base case (Appendix Table A6). Because the future benefits of HPV vaccination occur so far into the future, the impact of discounting is substantial. Without discounting future benefits, vaccination combined with status quo screening was cost saving at low per-dose costs, and vaccination followed by enhanced screening had costeffectiveness ratios approximately $50.0 \%$ lower (more attractive) than those found in the base case (Appendix Table A3). Additional sensitivity analyses are presented in the Appendix.

\section{DISCUSSION}

Formative research has been conducted in Peru regarding the health systems and policy context that will affect HPV vaccine introduction (10-14). The pilot study documented high coverage rates exceeding $80.0 \%$ in all Peru project sites, and relatively low rates of loss to follow-up after one or two doses (i.e., high rates of completion of three doses). Vaccination of schoolgirls was considered feasible because it was integrated into the national immunization program without reducing coverage rates of routine child immunizations. To add to this formative research, model-based simulation was conducted to estimate cervical cancer cases prevented, reduction in cancer incidence, and future lives saved. The cost-effectiveness of preadolescent vaccination combined with enhanced screening in adult women using HPV DNA testing, and the financial costs associated with introducing the new preadolescent vaccine, were also estimated.

Using the coverage rates and program delivery costs documented in the Peru demonstration project, it was estimated that preadolescent HPV 16,18 vaccination would reduce the risk of cervical cancer by $50.0 \%$. Vaccination of preadolescent girls followed by screening with HPV DNA testing five times per lifetime was projected to reduce the lifetime risk of cervical cancer by nearly $70.0 \%$. Furthermore, these strategies were found to be cost-effective.

Cost-effectiveness analyses demonstrate that prevention measures such as cervical cancer screening are clearly justified in low-resource countries, yet implementation of such measures is often hindered by affordability and political prioritization (17, 37, 38). Furthermore, health-related challenges in Peru (e.g., providing access to care in remote rural areas, and structuring services to reach women managing self-care along with household duties and employment) must also be addressed. Specific to cervical cancer screening, Peru faces difficulties associated with a multi-visit cytology-based program (e.g., health system infrastructure with treatment centers unevenly distributed throughout the country, high rates of loss to follow-up, etc.).

Preadolescent HPV vaccination combined with novel screening technologies provided to adult women could help to overcome the social, economic, and political disadvantages contributing to disparities in cervical cancer incidence and mortality; increase women's general access to care; and establish initial steps at a societal level to address structural barriers related to health systems and poverty 
TABLE 3. Extended analysis: health and economic outcomes associated with HPV 16 and 18 vaccination (82.0\% coverage) of preadolescent girls and various screening strategies, based on empirical data from an immunization pilot project and epidemiological data from cervical cancer screening collected in three regions, ${ }^{\mathrm{b}}$ Peru, 2006-2009

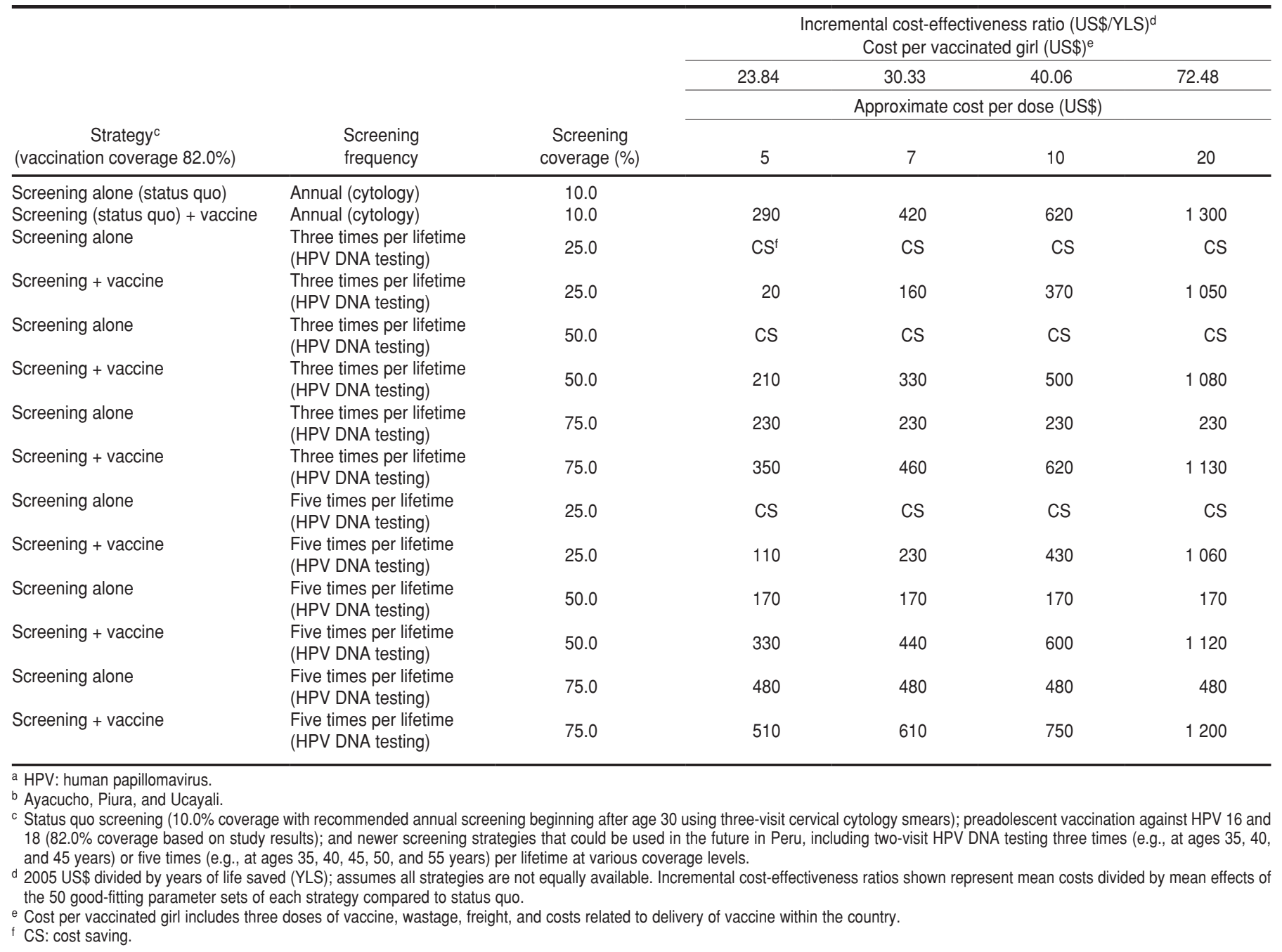

(37). Successful pre- or young adolescent immunization, possibly school-based, could provide a platform for delivering other adolescent health services. An organized screening program using HPV DNA testing, targeting women over age 30 , could serve the dual function of monitoring the prevalence of HPV 16 and 18, and performing simple and inexpensive treatment for detected precancerous lesions due to other HPV types detected at the time. Recommendations for screening programs include HPV DNA testing for primary screening due to its high test performance, suggesting that there is no rationale to introduce cytology in countries where high-quality cytologybased screening with high coverage of eligible women has not already been implemented $(6,39)$.
In the past several years, Peru has significantly increased the national immunization budget (over $600.0 \%$ since 2006), clearly making vaccination against preventable diseases (e.g., rubella, rotavirus, hepatitis $B$, influenza) a national priority (40). Evidence generated from the HPV vaccine demonstration project has been used to support Peru's most recent decision to introduce and scale up the HPV vaccine nationally for 300000 10-year-old girls in 2011, and order 600000 doses from the Pan American Health Organization (PAHO) Revolving Fund for less than US\$ 20 per dose (41).

While the specific investment for introducing the HPV vaccine in Peru is not known, the authors of the current study estimated that vaccinating $82.0 \%$ of 9 -year-old girls in a one-year campaign (2011) at a cost per dose of $\sim$ US\$ 20 would cost more than \$ 13 million for vaccines alone. To effectively reach this coverage, the national immunization program would need additional resources to cover program costs, increasing the total cost per dose to US\$ 24.16 per dose. At this total cost, the cost of a one-year campaign would be nearly US\$ 16 million. Considering vaccination will most likely be implemented for multiple years (e.g., 2010-2019), the undiscounted cost to vaccinate 10 cohorts of 9-year-old girls would range from about US\$ 50 million to about US\$ 160 million (at $\sim$ US\$ 5 to US\$ 20 per dose) (Appendix).

Financial estimates of HPV vaccination do not include the costs of providing screening and treatment, or the 
productivity costs (e.g., impact on the household), which are difficult to monetize. Women are often the caregivers and conduit for health provision in the household, playing central roles as managers of food security, wage earners, and caretakers of children and grandchildren and those who are ill (42-44). Improving the health of women thus contributes directly to the health of children as well as more broadly to poverty reduction. With the death or illness of a mother (and consequent loss of income and care), there is less money available for children's health care, education, and additional food, which may be reflected in increased health care costs for children, increased mortality risk, and decreased nutrition and schooling (37). Valuing the life of a woman and the welfare of children who lose their mothers (as maternal mortality has a strong adverse impact on child health) would make vaccination even more cost-effective and possibly cost-saving.

\section{Limitations}

One limitation of the current study is the exclusion of productivity costs, which contributes to the interpretation of the results as preliminary and conservative. Future analyses should prioritize enumeration and inclusion of spillover effects to other members of the household and society. Additional limitations to this analysis include gaps in the evidence base regarding vaccination, such as the duration of protection and possible necessity for a booster; crossprotection against non-targeted types; efficacy among immunocompromised populations; possibility of a two-dose schedule; and magnitude of herd immunity. Furthermore, while this analysis benefits from country-specific cost estimates of vaccine delivery and screening, it did not incorporate the costs associated with improving screening quality and efficiency, or establishing surveillance efforts.

\footnotetext{
1. Ferlay J, Shin HR, Bray F, Forman D, Mathers C, Parkin DM. GLOBOCAN 2008 v2.0, cancer incidence and mortality worldwide: IARC CancerBase No. 10 [Internet]. Lyon: International Agency for Research on Cancer; 2010. Available from: http://globocan.iarc.fr Accessed August 2010.
}

\section{Conclusion}

Using empirical data derived from a demonstration project to inform a model of cervical cancer in Peru, the current study assessed the benefits, cost-effectiveness, and financial cost requirements of vaccination, screening, and treatment. Motivated to contribute to the information needed by decision-makers to design immunization policy, the authors found that preadolescent HPV vaccination followed by enhanced HPV DNA screening in adult women could prevent two out of three cervical cancer deaths. Several strategies would be considered "good value" for resources invested, provided vaccine prices are low. While financial costs imply substantial immediate investments, the high-value payoff should motivate creative mechanisms for financing and scale-up of delivery programs. Peru's commitment to immunization programs for girls reflects policy makers' recognition that the investment goes beyond vaccinating a cohort of preadolescent girls. A preadolescent vaccination program will ultimately save women's lives, preserve the well-being of children and families, strengthen communities, and build health services capacity. It will also provide important information to neighboring countries developing strategies for reducing HPV infection.

Acknowledgments. The authors gratefully acknowledge the analytic assistance received from long-term partners at the Cervical Cancer Prevention Project, including the Catalan Institute of Oncology (Institut Català d'Oncologia, ICO) in Barcelona (Silvia de Sanjosé, F. Xavier Bosch, Xavier Castellsagué), and the International Agency for Research on Cancer (IARC) in Lyon (Gary Clifford, Silvia Franceschi, Jacques Ferlay), who were instrumental in providing data for empirical calibration and feedback on model assumptions. They also thank Stephen Resch, for his assistance with transforming vaccine costs collected empirically

\section{REFERENCES}

2. World Health Organization. Health statistics and health information systems: projections of mortality and burden of disease, 2004-2030 [Internet]. Geneva: WHO; c2009. Available from: http://www.who.int/healthinfo/ global_burden_disease/projections/en/ Accessed 9 October 2009. to a format required for the model, and D. Scott LaMontagne, for his provision of the vaccine coverage data, assistance with assumptions, and helpful review of the manuscript. The operational research that generated the data used in the model was implemented by the National Expanded Program for Immunization (Estrategia Sanitaria Nacional de Inmunizaciones, ESNI) of Peru's Ministry of Health (Ministerio de Salud, MINSA) in collaboration with PATH, and evaluated by MINSA/ESNI, the Instituto de Investigación Nutricional (IIN), and PATH, as part of the HPV Vaccines: Evidence for Impact project. The authors acknowledge all those who contributed to the operational research in Peru, including Mary E. Penny and Rosario Bartolini at IIN; the HPV Vaccines project team at PATH, including Irma Ramos, Inés Contreras, Jennifer L. Winkler, Amynah Janmohamed, Aisha Jumaan, D. Scott LaMontagne, Vivien Tsu, and Scott Wittet; the Government of Peru (senior officials and staff from MINSA and ESNI); the regional health officials in Ayacucho, Piura, and Ucayali, particularly those responsible for immunization, including Pilar Puza, Vilma Sullca, and Norma Beteta; and the district and local leaders and officials, health providers, teachers, school administrators, and civil society representatives in Ayacucho, Piura, and Ucayali. They also acknowledge the administrative support received by PATH throughout the research process from Rica Asunción, Inés Contreras, and Christina Smith. Finally, they express their gratitude to the parents, guardians, and children who participated in the research that produced the data used in this analysis.

Funding. This study was funded by the Bill and Melinda Gates Foundation (grant no. 30505), which had no role in the design and conduct of the study; the collection, management, analysis, and interpretation of the data; or the preparation, review, and approval of the report.
3. United Nations. World population prospects: the 2006 revision [CD-ROM]. Extended dataset. New York: UN Department of Economic and Social Affairs, Population Division; 2007.

4. FUTURE II Study Group. Quadrivalent vaccine against human papillomavirus to pre- 
vent high-grade cervical lesions. $\mathrm{N}$ Engl J Med. 2007;356(19):1915-27.

5. Paavonen J, Naud P, Salmerón J, Wheeler CM, Chow SN, Apter D, et al. Efficacy of human papillomavirus (HPV)-16/18 AS04adjuvanted vaccine against cervical infection and precancer caused by oncogenic HPV types (PATRICIA): final analysis of a doubleblind, randomised study in young women. Lancet. 2009;374(9686):301-14.

6. Cuzick J, Arbyn M, Sankaranarayanan R, Tsu $\mathrm{V}$, Ronco G, Mayrand MH, et al. Overview of human papillomavirus-based and other novel options for cervical cancer screening in developed and developing countries. Vaccine. 2008;26 Suppl 10:K29-41.

7. Goldie SJ, Gaffikin L, Goldhaber-Fiebert JD, Gordillo-Tobar A, Levin C, Mahé C, et al. Cost-effectiveness of cervical-cancer screening in five developing countries. $\mathrm{N}$ Engl J Med. 2005;353(20):2158-68.

8. Goldie SJ, Diaz M, Constenla D, Alvis N, Andrus JK, Kim SY. Mathematical models of cervical cancer prevention in Latin America and the Caribbean. Vaccine. 2008;26 Suppl 11:L59-72.

9. Colantonio L, Gómez JA, Demarteau N, Standaert B, Pichón-Rivière A, Augustovski F. Cost-effectiveness analysis of a cervical cancer vaccine in five Latin American countries. Vaccine. 2009;27(40):5519-29.

10. PATH; Instituto de Investigación Nutricional; Ministerio de Salud (PE). Resumen de la experiencia y evaluación del proyecto piloto de la vacuna contra el virus del papiloma humano en el Perú. Seattle: PATH; 2009.

11. Penny ME, Bartolini RM, Mosqueira NR. Evaluation of a one-year HPV vaccine delivery demonstration project in Peru. Lima: Instituto de Investigación Nutricional; 2009.

12. PATH; Instituto de Investigación Nutricional; and Ministerio de Salud, Estrategia Sanitaria Nacional de Inmunizaciones (PE). HPV vaccination in Latin America: lessons learned from a pilot program in Peru. Seattle: PATH; 2010. Available from: http://www.rho.org/files/ PATH_HPV_lessons_learned_Peru_2010.pdf Accessed 9 June 2011.

13. PATH; Instituto de Investigación Nutricional (PE). Shaping a strategy to introduce HPV vaccines in Peru: formative research results from the HPV Vaccines: Evidence for Impact project. Seattle: PATH; 2009. Available from: http://www.rho.org/files/PATH_FRTS Peru_eng.pdf Accessed 9 October 2009.

14. Penny M, Bartolini R, Mosqueira NR, LaMontagne DS, Mendoza MA, Ramos I, et al. Strategies to vaccinate against cancer of the cervix: feasibility of a school-based HPV vaccination program in Peru. Vaccine. 2011;29(31):5022-30.

15. Goldhaber-Fiebert JD, Stout NK, Ortendahl J, Kuntz KM, Goldie SJ, Salomon JA. Modeling human papillomavirus and cervical cancer in the United States for analyses of screening and vaccination. Popul Health Metr. 2007; 5(1):11.

16. Goldie SJ, Kim JJ, Kobus K, GoldhaberFiebert JD, Salomon J, O'Shea MK, et al. Cost-effectiveness of HPV 16,18 vaccination in Brazil. Vaccine. 2007;25(33):6257-70.

17. Goldie SJ, O'Shea M, Campos NG, Diaz M, Sweet S, Kim SY. Health and economic out- comes of HPV 16,18 vaccination in 72 GAVIeligible countries. Vaccine. 2008;26(32):4080-93.

18. Kim JJ, Kuntz KM, Stout NK, Mahmud S, Villa LL, Franco EL, et al. Multiparameter calibration of a natural history model of cervical cancer. Am J Epidemiol. 2007;166(2):137-50.

19. Kim JJ, Andres-Beck B, Goldie SJ. The value of including boys in an HPV vaccination programme: a cost-effectiveness analysis in a low-resource setting. Br J Cancer. 2007;97(9): $1322-8$.

20. Kim JJ, Goldie SJ. Health and economic implications of HPV vaccination in the United States. N Engl J Med. 2008;359(8):821-32.

21. Kim JJ,Kobus KE, Diaz M, O'Shea M, Van Minh $\mathrm{H}$, Goldie SJ. Exploring the cost-effectiveness of HPV vaccination in Vietnam: insights for evidence-based cervical cancer prevention policy. Vaccine. 2008;26(32):4015-24.

22. Diaz M, Kim JJ, Albero G, de Sanjosé $S$, Clifford G, Bosch FX, et al. Health and economic impact of HPV 16 and 18 vaccination and cervical cancer screening in India. Br J Cancer. 2008;99(2):230-8.

23. World Health Organization, Department on Immunization, Vaccines and Biologicals. Immunization coverage cluster survey-reference manual. Geneva: WHO; 2005. (WHO/ IVB/04.23). Available from: http://www. who.int/vaccines-documents/DocsPDF05/ www767.pdf

24. LaMontagne DS, Barge S, Le NT, Mugisha E, Penny ME, Gandhi S, et al. Human papillomavirus vaccine delivery strategies that achieved high coverage in low- and middleincome countries. Bull World Health Organ. 2011;89(11):821-30B.

25. GAVI Alliance. GAVI welcomes lower prices for life-saving vaccines [press release]. Geneva: GAVI Alliance; 2011 Jun 6. Available from: http://www.gavialliance.org/library/ news/press-releases/2011/gavi-welcomeslower-prices-for-life-saving-vaccines / Accessed 13 June 2011.

26. World Health Organization, Department on Immunization, Vaccines and Biologicals. Guidelines for estimating costs of introducing vaccines into the national immunization system [Internet]. Geneva: WHO; 2002. (WHO/ V\&B/02.11). Available from: http://whqlib doc.who.int/hq/2002/WHO_V\&B_02.11.pdf Accessed 1 April 2008.

27. World Health Organization. Immunization financing [Internet]. Geneva: WHO; c20082012. Available from: http://www.who.int/ immunization_financing/en/ Accessed 16 March 2008.

28. World Bank. World development indicators [Internet]. Washington: World Bank; c2008. Available from: http://data.worldbank.org/ data-catalog/world-development-indicators Accessed 24 January 2008.

29. International Labour Office. Women and men in the informal economy: a statistical picture. Geneva: ILO; 2002. Available from: http:// www.ilo.org/dyn/infoecon/docs/441/ F596332090/women $\% 20$ and $\% 20$ men $\% 20$ stat\%20picture.pdf Accessed 24 October 2005.

30. U.S. Department of Commerce International Trade Association. 1999 income data [Internet]. Washington: ITA; 2005. Available from: http:/ / ia.ita.doc.gov/wages/99wages/99wages.htm Accessed 24 October 2005.
31. World Health Organization. WHO-CHOICE (CHOosing Interventions that are Cost Effective). Geneva: WHO; 2009. Available from: http://www.who.int/choice/en/ Accessed 9 October 2009.

32. U.S. Department of Labor Bureau, International Labor Affairs. Wages, benefits, poverty line, and meeting workers' needs in the apparel and footwear industries of selected countries. Washington: ILAB; 2000. Available from: http://www.ssalt.org/pdfs/ United\%20States/US_DOL_Wages_Benefits Poverty_Line_and_Meeting_Workers\%27 Needs.pdf Accessed 24 October 2005.

33. DCP2.org. Disease Control Priorities Project [homepage on the Internet]. Washington: DCPP; c2009. Available from: http://www. dcp2.org/main/Home.html Accessed 9 October 2009 .

34. Drummond MF, O'Brien B, Stoddart GL, Torrance GW. Methods for the economic evaluation of health care programs. 2nd ed. New York: Oxford University Press; 1997.

35. Gold MR, Siegel JE, Russell LB, Weinstein MC Cost-effectiveness in health and medicine. New York: Oxford University Press; 1996.

36. World Health Organization. Macroeconomics and health: investing in health for economic development: report of the Commission on Macroeconomics and Health. Geneva: WHO; 2001. Available from: http://whqlibdoc.who. int/publications/2001/924154550x.pdf

37. Tsu VD, Levin CE. Making the case for cervical cancer prevention: what about equity? Reprod Health Matters. 2008;16(32):104-12.

38. Kim SY, Salomon JA, Goldie SJ. Economic evaluation of hepatitis B vaccination in lowincome countries: using cost-effectiveness affordability curves. Bull World Health Organ. 2007;85(11):833-42.

39. Franceschi S, Cuzick J, Herrero R, Dillner $\mathrm{J}$, Wheeler CM. EUROGIN 2008 roadmap on cervical cancer prevention. Int J Cancer. 2009;125(10):2246-55.

40. www.mef.gob.pe. Ministerio de Economía y Finanzas [homepage on the Internet]. Lima: MEF; c2010-2012. Available from: www.mef. gob.pe Accessed 20 December 2010.

41. Vicari A. Peru introduces nationwide HPV vaccination. Global Immunization News [Internet]. Geneva: World Health Organization; 2011 Feb 25. Available from: http://www. who.int/immunization/GIN_February_2011. pdf Accessed 15 June 2011.

42. Levin CE, Ruel MT, Morris SS, Maxwell DG, Armar-Klemesu M, Ahiadeke C. Working women in urban settings: traders, vendors, and food security in Accra. World Dev. 1999;27(11):1977-91.

43. Quisumbing A, Brown L, Feldstein HS, Haddad L, Peña C. Women: the key to food security. Food Policy Report. Washington: International Food Policy Research Institute 1995. Available from: http://www.ifpri.org/ sites/default/files/publications/fpr21.pdf

44. United Nations Population Fund. Food for the future: women, population, and food security. New York: UNFPA; 1997.

Manuscript received on 1 July 2011. Revised version accepted for publication on 23 May 2012. 
RESUMEN Objetivo. Calcular los beneficios, la rentabilidad (relación costo-efectividad), y los costos financieros (asequibilidad) de añadir la vacunación contra el virus del papiloma humano (VPH) al programa de tamizaje del cáncer cervicouterino en el Perú.

Repercusiones sanitarias y
económicas de la vacunación
de niñas preadolescentes
contra los tipos 16 y 18 del
virus del papiloma humano
y el tamizaje del cáncer
cervicouterino en las mujeres
adultas en el Perú

Palabras clave
Métodos. Se combinaron los datos probatorios (por ejemplo, cobertura, costos de prestación) de un proyecto piloto de vacunación contra el VPH llevado a cabo en el Perú con datos epidemiológicos, en un modelo matemático calibrado empíricamente para evaluar el tamizaje (prueba de ADN del VPH tres a cinco veces durante toda la vida) y la vacunación contra el VPH, según diferentes supuestos de costo, cobertura y eficacia. Los resultados del modelo incluían la reducción del riesgo de cáncer durante toda la vida, los casos de cáncer evitados, las vidas salvadas, los incrementos de la esperanza media de vida, los costos financieros a corto plazo y los costos económicos a largo plazo actualizados.

Resultados. Los bajos niveles de tamizaje actuales (cobertura del tamizaje citológico de $10,0 \%$ ) redujeron en $11,9 \%$ el riesgo de cáncer cervicouterino durante toda la vida en comparación con la ausencia de tamizaje. La adición de la vacunación de las niñas preadolescentes con la cobertura alcanzada en el programa piloto $(82,0 \%)$ produjo una reducción adicional de 46,1 \% y costaría menos de US\$ 500 por cada año de vida salvado a US\$ 7 la dosis, o de US\$ 1300 a US\$ 20 la dosis. Se calculó que el costo de las vacunaciones de un año era aproximadamente de US\$ 5 millones a unos US\$ 5 la dosis o de aproximadamente US\$ 16 millones a unos US\$ 20 la dosis, incluidos los costos programáticos. La mejora del tamizaje en las mujeres adultas combinada con la vacunación de las preadolescentes mostraba cocientes de rentabilidad incremental inferiores al producto interno bruto per cápita del Perú en el año 2005 (PIB US\$ 2 852, en dólares del 2009), y se consideraría rentable.

Conclusiones. La vacunación de las preadolescentes contra el VPH, junto con la mejora del tamizaje mediante la prueba de ADN del VPH en las mujeres adultas, podría prevenir dos de cada tres muertes debidas a cáncer cervicouterino. Varias estrategias se considerarían rentables en relación con los recursos invertidos, a condición de que el precio de la vacuna sea bajo. Aunque los costos financieros implican inversiones inmediatas sustanciales, el valor elevado de los beneficios debe motivar la elaboración de mecanismos creativos para financiar y extender los programas de prestación de servicios.

Infecciones por papillomavirus; neoplasias del cuello uterino; vacunas contra papillomavirus; vacunación; evaluación de costo-efectividad; Perú. 